\title{
REVIEW OF TRADITIONAL AND NATURAL METHODS OF TREATING ALZHEIMER'S DISEASE
}

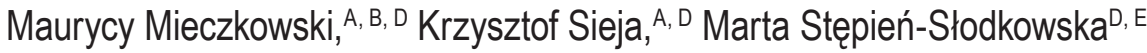 \\ University of Szczecin, Faculty of Physical Culture and Health Promotion, Szczecin, Poland \\ A Study Design; ${ }^{\mathrm{B}}$ Data Collection; ${ }^{\mathrm{C}}$ Statistical Analysis; ${ }^{\mathrm{D}}$ Manuscript Preparation; ${ }^{\mathrm{E}}$ Funds Collection \\ Address for correspondence: \\ Marta Stępień-Słodkowska \\ University of Szczecin, Faculty of Physical Culture and Health Promotion, Poland \\ Al. Piastów 40B building 6, 71-065 Szczecin, Poland \\ E-mail: marta.slodkowska1@wp.pl
}

\begin{abstract}
Ahstract The most common form of dementia in the elderly population is Alzheimer's disease (AD). World Health Organization (WHO) thus defines Alzheimer's disease: "a set of neurodegenerative brain symptoms, resulting in progressive impairment of memory, thinking, cognition, counting, language, ability to learn and assessing situations, which disturb everyday life". It usually develops in 65+-yearolds, and the risk of $A D$ in $85+$-year-olds is as high as $50 \%$. It has become a considerable threat to the society, given the longer life expectancy and an increase in the retirement-aged population. AD prevention and treatment methods described in this paper are still being developed and perfected. Studies on genesis of the disease aim at comprehensive understanding of its causes. New, alternative treatment methods are still sough. Researchers develop and test biomarkers that could facilitate early diagnosis.
\end{abstract}

Key WOrlls Alzheimer disease, Pharmacological Treatment, Nutrition, Physical Activity, Herbal Medicine

\section{Introduction. The Nature of the Disease}

The most common form of dementia in the elderly population is Alzheimer's disease (AD). It usually develops in 65+-year-olds, and the risk of AD in 85 +-year-olds is as high as $50 \%$ (Duthey, 2013). As reported Pąchalska (2009) the disease develops in $10 \%$ of people over 65 years old and in $30 \%$ of people aged above 85 years old. It is estimated that in the world suffers from 12 to 15 million people, while in Poland 200-250 thousand people (Gustaw et al., 2008; Pąchalska et al., 2009). It has become a considerable threat to the society, given the longer life expectancy and an increase in the retirement-aged population. In its initial stage, AD is often taken for dementia, which is a natural result of the aging process. It is not a consequence of neurodegenerative changes, and therefore the disease is diagnosed too late. This, in turn, limits the possibility of slowing down the development of AD and increasing patient's overall state.

World Health Organization (WHO) thus defines Alzheimer's disease: "a set of neurodegenerative brain symptoms, resulting in progressive impairment of memory, thinking, cognition, counting, language, ability to learn 
and assessing situations, which disturb everyday life" (Kaliszan, Macur, 2010). Despite still unknown pathogenesis mechanisms, $A D$ is classified as tauopathy, i.e. a disease related to tau protein pathology, which leads to aggregation of neurofibrillary tangles, beta-amyloid formations (senile plaques) (Ling et al., 2011), as well as oxidative stress (Szwed, Miłowska, 2012).

$A D$ results in significant costs of treatment, due to increased population of the elderly. In the US, approximately 5.4 million people suffer from AD, and the cost of treatment is estimated at 200 billion USD (Anderson, 2013). According to the $\mathrm{WHO}$, costs of treatment and care for dementia patients all over the world amount to 604 billion USD. In 2012, WHO estimated that there were 35.6 million people worldwide who suffered from dementia. WHO predicts that by 2030 this number will have doubled, and by 2050 it will have tripled (Duthey, 2013). The increased number of patients will generate higher costs. According to demographic forecasts, in Poland in 2030 there will be 9.1 million of $60+$-year-olds; $10 \%$ of them will suffer from dementia.

Attempts to identify and analyze AD biomarkers are still ongoing. Possibly, beta-amyloid $(A \beta)$ build-up might be detected even 15 years before the onset of the disease, based on blood and cerebrospinal fluid tests. A $\beta$ level one of isoforms decreases approx. 25 years before the onset of the disease (Anderson, 2013). Assessing the level of total $A \beta$ in patients with $A D$ in CSF using ELISA method, showed no changes compared to those without dementia (Blennow, 2004). However, further studies have shown the existence of two isoforms of $A \beta$ : containing 40 amino acids of $A \beta 40$ and 2 containing 42 amino acids, $A \beta 4$ which is the dominant form of brain streaks and more toxic. Different methods (ELISA, Western blot, UREA SDS-PAGE - Western blot) showed reduced by approx. 50\% $A \beta 42$ in the CSF of patients with AD. This reduction was caused probably by storing it in senile plaques. Should this revelation be confirmed, it might become a very effective method of diagnosing high-risk groups.

Another potential method of identifying AD's onset might be MRI to measure atrophy in the hippocampus as a biomarker of AD development (Greene, Killiany, 2012). Researchers from Boston found different changes in various parts of the hippocampus in the aging process, as well as changes in glucose metabolism in some parts of the brain of the $A D$ patients. Relation between atrophy and beta-amyloid build-up in $A D$ is still being researched, but it has already been found (Chételat et al., 2010) that there is a strong correlation between these two processes in the early stage of $A D$. The research revealed general and specific atrophy in patients with subjective cognitive disorders resulting from beta-amyloid build-up, while it was not revealed in patients with medium cognitive disorders or AD. AD-related atrophy results in neuron and synapse loss, mostly in hippocampus, which leads to impaired cognitive skills. The most popular hypothesis is the impact of production and build-up of beta-amyloid on gray matter loss. Nevertheless, the relation between these two pathological processes is still unknown. Research on the relation between beta-amyloid and atrophy does not assume direct and total impact of beta-amyloids on AD. It rather focuses on their neurodegenerative nature in the build-up areas, as well as indirect impact on other areas such as hippocampus. In-depth research is important, as - potentially - anti-amyloid therapy might be used in the early stages to slow down atrophy and decrease the loss of cognitive functions. One of promising method of treating $A D$ in the future is photothermal therapy (Meng, 2012). Tested on mice, it showed very optimistic results and effectively bypassed the physical barrier between blood and brain.

\section{Pharmacological Treatment}

In the pharmacological treatment of $A D$, acetylcholinesterase inhibitors are used. In Poland, donepezil, rivastigmine, galantamine and taurine are used (Kijena et al., 2008). They affect cholinergic transmission, increasing 
the activity level of the cholinergic system (Gabryelewicz, Mandacka, 2013). The treatment usually involves the maximum tolerated dosage. The drugs are prescribed to patients with diagnosed, quick progress of the dementia symptoms. Drugs stop the progress of the disease for 2 years for a small proportion (approx. 20\%) of patients (Leszek, 2013). They stimulate cognitive functions, orientation, visual and spatial functions, alertness, attention and learning. They also affect other functions, such as memory and language functions, but with weaker effects (Kijena et al., 2008). Neuroprotective effect of the treatment is reported, especially of donepezil in cholinergic neurons of rats (Leszek, 2013), but donepezil's mechanism has not been fully discovered yet. A literature review made by Briggs (2006) demonstrated the effect of the use of inhibitors. However, no detailed data on their impact on the social aspects of the disease. There is also no possibility of identifying persons before treatment which obtains a positive therapeutic response inhibitors. There is also no basis to determine which one is more effective despite the differing mechanisms of action.

Memantine, NMDA receptor antagonists, is used in medium and late dementia. It may also be used for early dementia, based on NMDA receptors' role and glutamate effects (Sobów, 2014). It needs to be noted, however, that there is still no research which would prove its effectiveness in the early stage of cognitive impairment, Meanwhile, memantine helps with many neurodegenerative problems. It is also recommended by the FDA to treat AD (Leszek, 2013). As a consequence, only acetylcholinesterase inhibitors and NMDA antagonists are currently approved in $A D$ treatments. There are few randomized studies, which compared mementine to other therapies, mostly acetylcholinesterase inhibitor, that have shown to slow progression of disorders (Gauthier et al., 2007).

Kinase-inhibitors are also used in AD treatment, despite lack of detailed research on kinase's impact on AD. There are, however, reasons to believe that they combat key symptoms of neurodegeneration, or to be more precise: neurotoxic functions, neuroinflammation and phosphorylation of tau protein (Savage, Gingrich, 2009). Use of kinase seems promising due to its impact on regulations of various biological processes. It is, however, challenging to carry out detailed studies on their properties, especially in vivo tests. Striving for selectiveness (to limit potential toxic effects) lets us mention kinase only as potential, alternative method which might become AD treatment in the future.

Ibuprofen and glutathione are used in AD treatment (Pinnen et al., 2011), based on the belief that nonsteroidal anti-inflammatory drugs and anti-oxidation therapy may limit the development of $A D$. They fight inflammation and oxidative stress in AD-affected cells. Glutathione neutralizes various oxidants. Italian researchers created a molecular combination of ibuprofen and glutathione with amide binding. They based their study on an assumption that according to epidemiologic studies, NSAIDs decrease incidence of AD amongst patients (Tendera, Kruk, Biała, 2010) and slows down the onset and development of the disease, as well as decreases the loss of cognitive functions. Ibuprofen and glutathione were also tested in rats in order to determine harmfulness of beta-amyloids to cognitive structures and functions. Study results revealed better long-term spatial memory in rats that were treated with ibuprofen + glutathione.

Studies of relation between biology and genesis of AD recommend the use of medical methyl blue (Tęgowska, Wosińska, 2011). According to a study which involved 300 persons, the 30,60 and $100 \mathrm{mg}$ dosage 3 times per day resulted in slowing down AD development after one year. Numerous benefits of methyl blue are highlighted: reduced number of free radicals, lowering the sensitivity threshold to adrenaline, noradrenaline and dopamine. The research also revealed a decrease of NOS gene expansion, which occurs at the early stage of the disease. Given these properties, it is fair to say that there is a significant potential of improving metabolic functions of brain of AD patients. 
Another example of pharmacological treatment is immunotherapy with beta-amyloids (Tendera et al., 2010). It is based on a study with mice. First active immunization was carried out with QS-21 and CAD-106 antibodies (Seeman, Seeman, 2011); the second one, passive with anti-beta-amyloid antibodies (Kwieciński, 2010), was considered to be safer. Studies highlight benefits of both methods: restoring synapse and neuron functions, reducing amyloids and improving patients' behaviors. Immunotherapy needs further research to eliminate risks of auto-immune diseases and encephalitis.

Impact of insulin in AD treatment should also be discussed. Brain metabolism studies and related to it reduced glucose consumption point to the fact that glucose concentration is accompanied by increased (improved) memory of patients. Perhaps it resulted not only from glucose, but also insulin. Type 2 diabetes is seen as one of risk factors of $A D$, due to resistance of insulin receptors. Among many scientific revelations, de Felice et al. proposed that $A D$ might be a form of diabetes that occurs only in the brain (Tęgowska, Wosińska, 2011).

\section{Non-Pharmacological Treatments}

$A D$ patients are treated with reality orientation therapy, i.e. giving information about current time and place. It should help patients with understanding their whereabouts. To improve patients' orientation, calendars, watches, newspapers and news programs are recommended. These measures prevent loss of sense of time and help train memory (Długosz-Mazur, Bojar, Gustaw, 2013). Another method is validation therapy, which ensures comfort and acceptance of people around the patient. In the validation therapy, patients' remarks are accepted, even if they are not realistic. It serves to stimulate appropriate social behaviors, improving well-being and decreasing anxiety and fear. It is recommended to avoid confrontation with patients and stir up conversation on another topic. Third method is a reminiscence therapy, based on memories and recollections of patients. It involves talking about actions or events from patient's past, using some objects to help access old memories. Effectiveness of these therapies is still verified; some studies suggest only temporary improvements. Method descriptions also highlight negative effects, such as sense of frustration. Analysis of validation therapy report improvement, as well as apathy, agitation and irritability. These therapies are meant to maintain patient' cognitive functions and comfort of life. It is important, as it significantly affects dementia patients' behavior.

$A D$, being a type of dementia, results in behavioral changes. These are called BPSD (behavioral and psychological symptoms of dementia) (Ponichtera-Kasprzykowska, Pękala, Sobów, 2013). It is important, as studies revealed a relation between BPSD and negative effect on cognitive function and self-reliance loss, as well as higher risk of falling and injuries. Pharmacological treatment is not effective enough and it increases the risk of complications, such as cerebral stroke or heart attack. The literature distinguishes four approaches to development mechanisms of these behaviors: genetic/biological approach; behavioral approach; oversensitivity to stress; unfulfilled needs. These approaches do not exclude each other; therefore, it is possible that patients display a couple of them.

Non-pharmacological treatment involves various forms of interventions: sensory methods, e.g. music therapy, multi-sensory therapy, massages, music and aromatherapy. Aromatherapy with essential oils is used both in palliative care, as well as in case of dementia. The most recommended oils are: lavender, boswellia, ylang ylang they are relaxing and help decrease to some extent anxiety and fear (Walden-Gałuszko, Gaworska-Krzemińska, 2012). Another group of methods involve contact with animals, such as therapy dogs. There are also methods based on activities which help patients give structure to their lives, mostly by means of occupational therapy. They are 
recommended due to their preventive nature for patients with behavior disorders (Ponichtera-Kasprzykowska et al., 2013).

\section{Nutrition}

Nutrition is an important aspect, as it is indispensable part of our lives and affects human development on every stage of ontogenesis, therefore it may treat and prevent AD. Most of all, unhealthy eating habits may lead to various diseases: excessive consumption, unhealthy diet, food contaminated with heavy metals and highly processed food with a large number of colorants. As long-term effects are not fully known, it is assumed that some of these risk factors may lead to diseases (Gawędzki, Roszkowski, 2013). Healthy diet may be an alternative in AD prevention. Shops do not offer food tailored to the needs of 65+-year-olds. Thoughtfully designed and popularized diet might improve seniors' health and prevent many diseases (Gawęcki, Roszkowski, 2013). One should also remember the impact of advanced age on the bodies of the elderly: decrease in muscle mass, increase of fatty tissue lead to higher risk of lipid disorders, hypertension and diabetes. At the old age, absorption and metabolic processes are weak, which leads to micro and micro element deficit. Another threat to seniors' health is malnutrition (Dudkowiak, Gryglas, Poniewierka, Poniewierka, 2013), which results in cognitive function impairment and excessively limited physical activity.

One of dietary ingredients important in AD are antioxidants (Tendera et al., 2010) as well as vitamin C and $\mathrm{E}$. They help remove free radicals from the body. Low level of antioxidants increases oxidative stress and accelerates the aging process, as well as contributes to inflammations (Dudkowiak et al., 2013). It has not been confirmed scientifically that vitamin $E$ limits the development of AD (Jaworski, 2010). It is, however, noted that insufficient consumption of vitamin E may lead to worse results in cognitive function tests (Dudkowiak et al., 2013). One study revealed that vitamin $\mathrm{C}$ increases activity of acetylcholinesterase in tests on mice. Another study showed a positive effect of vitamin C and $E$ on cognitive functions in old mice (Tendera et al., 2010). Vitamin B12 and B6, as well as folic acid, may reduce the risk of developing AD (Jaworski, 2010). It is supported by the fact that these vitamins correlate with correct reactions with homocysteine, which is believed to be an independent factor in atherosclerosis; when increased, it may also impact the speed of anti-amyloid build-up (Dudkowiak et al., 2013).

Ketogenic diet (Liśkiewicz, Jędrzejowska-Szypułka, Lewin-Kowalik, 2012) is a high-fat and low-carbohydrate diet, used therapeutically in epilepsy. It delivers $80 \%$ of fat, $15 \%$ of protein and only $5 \%$ of carbohydrates from the food, at a $4: 1$ ratio. The fat ratio may also be $3: 1$ or $2: 1$. The main source of fat are medium- and long-chain triglycerides. Ketogenic diet was developed in 1971 by Peter R. Huttencholer. Research confirmed its neuroprotective effects. Ketogenic diet affects the insulin level in blood and insulin receptors in cerebral cortex and hippocampus, which impacts memory and ability to learn (effect of insulin in beta-amyloid secretion, leading to their build-up).

The Mediterranean diet is promoted as one of the most effective diets in AD prevention (Dudkowiak et al., 2013). Numerous epidemiologic studies reveal lower incidence of dementia, resulting from frequent consumption of fish and sea food. This diet is based on fish, vegetable oils (incl. olive oil), fruit and vegetable and reduces the consumption of red meat. Diet rich in omega- 3 and omega- 6 fats is a desirable form of AD prevention. Mediterranean diet is also used in treatment of diabetes and hypertension.

Caffeine, a known stimulant of the central nervous system, increases levels of serotine and acetylcholine neurotransmitters related to memory. Its consumption increased adenosine receptors in animal brain (Tendera et al., 2010). Studies showed a correlation between cognitive functions of humans and regular consumption of caffeine; 
they also pointed to other benefits of small dosage of caffeine, due to its neuroprotective effects. However, this type of research was only carried on experimental models, therefore it is difficult to prove actual effect of caffeine.

Nicotine and nicotine receptor antagonists may affect the cognitive functions in $A D$. Its neuroprotective effects are based on stimulation of neural nicotine acetylcholine receptors (Kaliszan, Macur, 2010). Direct stimulation results in dopamine, serotonin and glutamate release, which are related to learning and memory in presynaptic receptors. Beneficial effects were discovered in studies devoted to effects of smoking on Parkinson disease and improved cognitive functions in humans, which suggest a positive effect of nicotine in AD treatment. This form of treatment, however, needs to be approached cautiously, given the negative effect of smoking on human health, which is still a controversial and undiscovered issue (Dudkowiak et al., 2013).

Cannabinoids may reduce neuropathies, according to research in 2007 (Tkaczyk, Florek, Piekoszewski, 2012) and have neuroprotective effect. Studies suggest that using cannabinol tracts may help treat AD more effectively, but there are still no comprehensive studies. Hopefully, more studies will follow, as the issue of cannabinoids and therapeutic marihuana raises significant interest among researchers.

\section{Physical Activity}

There are no proved correlations between physical activity and AD (Dudkowiak et al., 2013). Physical activity improves level of fitness and agility in the old age, as well as impacts other diseases, such as diabetes and hypertension. As diabetes seems to increase the risk of AD, National Institute of Aging is currently conducting studies on physical activity and prevention of AD (https://clinicaltrials.gov/ct2/show/NCT02000583, 2015). The research will conclude in January 2018 with conclusions about impact of physical activity on reduced AD risk. In May 2016 another study is scheduled to finish; it focuses on different forms of physical activity on thought processes. The study involves subjects with medium cognitive impairment (https://clinicaltrials.gov/ct2/show/ NCT02237560, 2015). As far as the elderly are concerned, the emphasis should be put on increasing muscle flexibility, as its loss is a natural consequence of the aging process. Exercise is also recommended to increase the limited motion range of joints and balance - as falling down is common among the elderly. It is often a consequence of metabolic disorders, such as hypoglycemia, dehydration and neurological disorders: strokes, neuropathy or dementia (Niechwiadowicz, Klimczyk, 2010). For example, Wielkopolskie Stowarzyszenie Alzheimerowskie (AD Association in the Wielkopolskie region in Poland) recommends physical activity, mostly isometric exercises to patients with light dementia. Preferably, exercise should be done in groups. In case of advanced dementia, it is better to use individual exercises: a short walk or workout on a mattress and relaxation techniques. Beneficial effect of physical activity of the brain was showed in studies on animals (Jaworski, 2010). Physical activity promoted neurogenesis and lengthened the longevity of nerve cells in tests on animals; it also increased plasticity of synapses.

\section{Herbal Medicine}

Studies revealed therapeutic effect of neuroactive substances in Lamiaceae plants (Ożarkowski et al., 2009). They were proved to stop enzymes which affect the central nervous system in development of AD. The studies focused on effectiveness of substances in rosemary, melissa and Salvia Miltiorrhiza (red sage). As for rosemary, rosmarinic acid has antioxidant, anti-inflammatory and antimicrobial properties (Kubis, Janusz, 2008). Authors of studies on rosemary wrote: '(...) that most of extracts from these plants inhibited activity of acetylcholinesterase in vitro'. It was also revealed that some active ingredients of the polyphenol group, including flavonoid from 
Lamiaceae plants, inhibited aggregation of beta-amyloid in vitro (Ożarkowski et al., 2009). However, as there are no studies on animals, this form of treatment is only potentially more beneficial than pharmacological treatments.

Another substance that might help with $A D$ treatment comes from Morus Alba (white mulberry). Leaves of this plant contain large proportion of vitamin C, B, D and E (Krzemińska, 2011). They are used in Korea, Japan and Chile to make anti-diabetic tea. A study on rats revealed lowered level of glucose after 5 weeks. Extract from leaves of Morus Alba was also reported to inhibit and lower neurotoxicity of beta-amyloids; it is also believed to have anti-oxidation properties, due to high concentration of quercetin and rutin. Given the antioxidant properties, vitamin $C$ and $E$ and its effect on beta-amyloids, Morus Alba might be another method of preventive AD treatment. Using Morus Alba in treatment of $A D$ requires further in-depth studies.

\section{Conclusion}

$A D$ prevention and treatment methods described in this paper are still developed and perfected. Studies on genesis of the disease aim at comprehensive understanding of its causes. New, alternative treatment methods are still sough. Researchers develop and test biomarkers that could facilitate early diagnosis. Using ibuprofen and glutathione, immunotherapy, methyl blue and kinase inhibitors to slow down the onset of the disease give increasingly promising results. All of these therapies rely primarily on the action of symptomatic and bring only limited clinical results and used drugs do not affect the mechanism of the disease process (Bilikiewicz, Bidzian, 2007). However, currently in clinical trials are measures that can affect the disease process.

At the same times, other, non-pharmacological methods are researched, which could be available to majority of those suffering from AD. Ketogenic diet is recommended, as it is used in epilepsy and potentially has neuroprotective properties. Mediterranean diet is also popularized, as its beneficial effects are becoming commonly known. Antioxidants' effect has already been proved; vitamin $\mathrm{C}$ and $\mathrm{E}$ relieve oxidative stress, while caffeine (used in small dosage) has neuroprotective properties. Healthy nutrition and diet seem to have long-lasting effects on maintaining good physical and mental state on every stage of life. Hopefully, it will help combat AD more effectively in the future.

Studies are carried out to determine pro-health benefits of physical activity; however, there is no explicit confirmation of relation between physical activity and development of the disease. On the other hand, positive effect of physical activity on the general improvement of quality of life and reduced risk of many diseases is well known. Researchers also study potential impact of psychoactive substances on the development of AD. It is, however, limited by their known negative effect on many functions of the organism. Searching for new treatments leads to creating new hypothesis, e.g. relation between insulin/diabetes and $A D$.

It seems justified to look for new herbal substances that would effectively treat $A D$ as well as prevent it. The existing methods and new solutions give hope for successful combat with Alzheimer's disease.

\section{Referencess}

Anderson, D.C. (2013). Alzheimer's Disease Biomarkers: More Than Molecular Diagnostics. Drug Development Research, 74.

Bilikiewicz, A., Bidzan, L. (2007). Current trends in Alzheimer's Disease pharmacotherapy. Farmakoterapia w psychiatrii i neurologii, 2, 69-74.

Blennow, K. (2004). Cerebrospinal fluid protein biomarkers for Alzheimer's disease. The Journal of the Society for Experiment NeuroTherapeutics, 1 (4), 213-225. 
Chételat, G., Villemagne, V.L., Bourgeat, P., Pike, K.E., Jones, G., Ames, D., Ellis, K.A., Szoeke, C., Martins, R.N., O’Keefe, G.,J., Salvado, O., Masters, C.L., Rowe, C.C. (2010). Relationship between Atrophy and Beta-Amyloid Deposition in Alzheimer Disease. Annals of Neurology, 67 (3).

Długosz-Mazur, E., Bojar, I., Gustaw, K. (2013). Niefarmakologiczne metody postępowania u chorych z otępieniem. Medycyna Ogólna i Nauki o Zdrowiu, 19 (4).

Dudkowiak, R., Gryglas, A., Poniewierka, A., Poniewierka, E. (2013). Rola wybranych czynników ryzyka w etiopatogenezie i przebiegu choroby Alzheimera. Aktualności Neurologiczne, 13 (2).

Duthey, B. (2013). Alzheimer Disease and other Dementias, Priority Medicines for Europe and the World. A Public Health Approach to Innovation, Background Paper 6.11.

Gabryelewicz, T., Mandecka, M. (2013). Wyzwania terapii otępienia w chorobie Alzheimera. Aktualności Neurologiczne, 13 (2).

Gauthier, S., Wirth, Y., Möbius, H.J. (2005). Effects of memantine on behavioural symptoms in Alzheimer's disease patients: an analysis of the Neuropsychiatric Inventory (NPI) data of two randomised, controlled studies. Int. J. Geriatr. Psychiatry, 20, 459-464.

Gawęcki, J., Roszkowski, W. (2013). Żywienie u progu i schyłku życia. Poznań: Wydawnictwo Uniwersytetu Przyrodniczego.

Greene, S.J., Killiany, R.J. (2012). Hippocampal Subregions Are Differentially Affected in the Progression to Alzheimer's Disease. The Anatomical Record, 295.

Gustaw, K., Bełtowska, K., Makara-Studzińska, M. (2008). Reakcje emocjonalne opiekunów z demencją- potrzeba pomocy społecznej. Przegląd Lekarski, 65 (6), 304-307.

Jaworski, M. (2010). Łagodzenie objawów poznawczych poprzez stosowanie odpowiedniej diety u osób z chorobą Alzheimera, Neuropsychiatria i Neuropsychologia, 5 (3-4).

Kaliszan, R., Macur, K. (2010). Na tropie środków przydatnych w terapii lub profilaktyce choroby Alzheimera. Forum Medycyny Rodziny, 4 (1).

Kiejna, A., Pacan, P., Trypka, E., Sobów, T., Parnowski, T., Kłoszewska, I., Bidzan, L., Borzym, A., Antoniak, D., Cieślak, U., Paszkowska, E., Jarema, M. (2008). Standardy leczenia otępień. Psychogeriatria Polska, 5 (2).

Krzemińska, S. (2011). Morwa biała-niedoceniony skarb. Świat Farmacji, 6.

Kubis, A.M., Janusz, M. (2008). Choroba Alzheimera - nowe możliwości terapeutyczne oraz stosowane modele eksperymentalne. Postępy Higieny i Medycyny Doświadczalnej, 62.

Kwieciński, H. (2010). Nowości w diagnostyce i terapii schorzeń neurologicznych. Przewodnik Lekarza, 4.

Leszek, J. (2013). Leczenie farmakologiczne choroby Alzheimera, Farmakoterapia w Psychiatrii i Neurologii, 3-4.

Ling, S., Zhou, J., Rudd, J.A., Hu, Z., Fang, M. (2011). The Recent Updates of Therapeutic Approaches Against Ab for the Treatment of Alzheimer's Disease. The Anatomical Record, 294.

Liśkiewicz, A., Jędrzejowska-Szypułka, H., Lewin-Kowalik, J. (2012). Characteristics of ketogenic diet and its therapeutic properties in central nervous system disorders. Annales Academiae Medicae Silesiensis, 66 (6).

Meng, L., Xinjian, Y., Jinsong, R., Konggang, Q., Xiaogang, Q. (2012). Using Graphene Oxide High Near-Infrared Absorbance for Photothermal Treatment of Alzheimer's Disease. Advanced Materials, 24 (13).

National Institute of Aging, Effect of Aerobic Exercise on Pathophysiology of PreClinical Alzheimer's Disease, ClinicalTrials.gov ID:NCT02000583. Retrieved from: https://clinicaltrials.gov/ct2/show/NCT02000583.

National Institute of Aging, The Cognitive Benefits of Interactive Mental and Physical Exercise for Mild Cognitive Impairment (MCI), ClinicalTrials.gov ID:NCT02237560. Retrieved from: https://clinicaltrials.gov/ct2/show/ NCT02237560.

Niechwiadowicz, T., Klimczyk, A. (2010). Wybrane zagadnienia z pielęgniarstwa geriatrycznego. Wrocław: Continuo.

Ożarkowski, M., Mikołajczak, P., Bobkiewicz-Kozłowska, T., Kujawski, R., Mrozikiewicz P. (2009). Neuroaktywne związki roślin leczniczych rodziny Lamiaceae wykazujące potencjalne korzystne działanie w leczeniu choroby Alzheimera. Herba Polonica, 55 (4).

Pąchalska, M., Bidzan, L., Pufal, A., Bidzan, M., Łukaszewska, B. (2009). Dynamika zaburzeń zachowania w otępieniu typu Alzheimera. PsyhoGeriatria Polska, 6 (2), 43-58.

Pinnen, F., Sozio, P., Cacciatore, I., Cornacchia, C., Mollica, A., lannitelli, A., D’Aurizio, E., Cataldi, A., Zara, S., Nasuti, C., Di Stefano, A. (2011). Ibuprofen and Glutathione Conjugate as Potential Therapeutic Agent for Treating Alzheimer's Disease. Archiv der Pharmazie - Chemistry in Life Sciences, 11. 
Ponichtera-Kasprzykowska, M., Pękala, K., Sobów, T. (2013). Niefarmakologiczne strategie postępowania w zaburzeniach zachowania towarzyszących otępieniu. Aktualności Neurologiczne, 13 (4).

Savage, M.J., Gingrich, D.E. (2009). Advances in the Development of Kinase Inhibitor Therapeutic for Alzheimer's Disease. Drug Development Research, 70.

Seeman, P., Seeman, N. (2011). Alzheimer's Disease: b-Amyloid Plaque Formation in Human Brain. Synapse, 65.

Sobów, T. (2014). Memantyna w łagodnych zaburzeniach poznawczych i otępieniu alzheimerowskim o nasileniu lekkim: przesłanki teoretyczne, badania kliniczne i rekomendacje stosowane. Aktualności Neurologiczne, 14 (1)

Szwed, A., Miłowska, K. (2012). Rola białek w chorobach neurodegeneracyjnych. Postępy Higieny i Medycyny Doświadczalnej, 66.

Tęgowska, E., Wosińska, A. (2011). Rola nauk biologicznych w zrozumieniu genezy i nowego podejścia terapeutycznego do choroby Alzheimera. Postępy Higieny i Medycyny Doświadczalnej, 65.

Tendera, K., Kruk, M., Biała, G. (2010). Alzheimer disease: causes, symptoms and pharmacotherapy. Annales UMCS, Sectio DDD, Pharmacia, XXIII (3), 13.

Tkaczyk, M., Florek, E., Piekoszewski, W. (2012). Marihuana i kanabinoidy jako leki. Przegląd Lekarski, 69 (10).

Walden-Gałuszko, K., Gaworska-Krzemińska, A. (2012). Opieka paliatywna. Wrocław: Wydawnictwo Elsevier Urban \& Partner.

Cite this article aS: Mieczkowski, M., Sieja, K., Stępień-Słodkowska, M. (2016). Review of Traditional and Natural Methods of Treating Alzheimer's Disease. Central European Journal of Sport Sciences and Medicine, 16 (4), 67-75. DOI: 10.18276/cej.2016.4-07. 
